\title{
The Impact of Dividend Distribution on Cash Flow Predictability in Tehran Stock Exchange
}

\section{Mohammad Nazaripour}

Department of Accounting, University of Kurdistan, Sanandaj, Iran Corresponding Author. E-mail: mnazaripour@yahoo.com

\section{Mahmud Ramezani}

MSc in Accounting

\section{Omid Motamedi}

MSc in Accounting

\section{Doi:10.5901/mjss.2015.v6n6s2p591}

\begin{abstract}
This study investigates the impact of dividend distribution on the predictability of cash flow data. Predictability is defined as the ability of an accounting variable to predict future cash flows. Dividend Distribution among shareholders is an indicator for predicting cash flow. The period of this study is from 2007-2012 and the sample is 121 companies listed on the Tehran stock exchange. In this research, the dependent variable is cash flow predictability and the independent variable is dividend distribution as well as control variable is firm size. Multivariate regression analysis was used to test the research data. According to the research findings, cash flow forecasting has normal distribution and the changes in future cash flows are because of changes in dividend distribution (cash distributions to shareholders). The research findings show firm size has the same effect on free cash flow and operating cash flow.
\end{abstract}

Keywords: Dividend Distribution, Cash Flow Predictability, Firm Size, Free Cash Flow, Operating Cash Flow and Tehran Stock Exchange

\section{Introduction}

Accounting can be defined as the process of identification, measurement, classification, and reporting the financial statements (data), in order to meet the requirements for a conscious judgment and taking logical decisions to identifying, measuring, and classifying the financial events which are influencing the organizations and commercial units and reporting the effects of such events on the authorities. As you know, investors take decisions about buying, selling, or keeping and toward this aims or issues they need the relevant data. They are paying attention to the following factors in their decision makings:

1) The cost and timing of the oncoming cash revenues as dividend.

2) Vagueness's concerning these kinds of oncoming cash revenues.

3) Revenues which are being earned out of selling shares or repurchasing shares.

Cash is one of the main and vital resources of any economic unit and creating balance between cash and cash requirements is one of the main factors of the economic policy and the continuation of activity in an economic agency. Moreover, cash flow plays a vital role. In this manner, from an intra-organizational view, the ability to predict the oncoming activities, specifically cash flow, has made it possible to manage the affairs in the most efficient way and it will end in taking optimal operational decisions, investment, and financing. On the other hand, lots of decisions which are being made by extra-organizational beneficiaries are based on oncoming data concerning cash flow. (Jannat Rostami, 1999).

\subsection{Explanation and expression of the research question}

Due to the considerable significance of cash flow for the success of economic units and its necessity for the continuation of the survival of these units, predicting cash flow as a part and parcel of financial programming is being considered as 
one of the most important issues which is being specifically prized on behalf of managers of an economic unit. Also, predicting cash flow is one of the main interests of diverse economic groups such as investors, grantors of state-owned economic units, and financial analysts.

Dechow et al (1998), recommended the distribution of cash among shareholders to be considered as a criterion for oncoming cash flow. They illustrated that dividend shares bestow a valuable theoretical basis to the investors to use in the prediction models of oncoming cash flow, since the amount of dividend shares reflect the oncoming policies and strategies of managers and illuminates the oncoming perspective of a profit-making organization. In addition, they expressed that the distribution of cash among shareholders has a considerable influence on deducing the firm size in order to predict the concept of free cash flow, while the size of a company has no effect on the operating cash flow. Also, they stated that the firm size is a determining factor for the operational constancy but not for investment constancy.

In general, according to the results of the activities which are being done by Dechow et al (1998), alongside with the activities which are being done by Dechev and Tang (2009), they recommend that companies with the maximum amount of net cash flow distribution among their shareholders produce the maximum amount of constancy in the cash flow which in turn they recommend that these companies do the maximum amount of cash flow prediction.

\subsection{Importance and necessity of research}

Financial Accounting Standard Board considers one of the significant aims of financial reporting as being relevant to producing revenues (profits), cash flow, and commitment data to be useful for predicting oncoming cash flow. Cash flow prediction to influence investors and as a cost for creating and maintaining large-scale investments in the expected timings and concerning the vagueness's in cash flow is significant. Most of the previous studies (reviews of the literature), have identified the elements of operating cash flow and have emphasized this point that the operational cash flow should be among homogeneous companies. Also in this research compatible with the research which was being done by Dechow et al (1998), besides the idea or imagination in a rather different way they get into the story of bestowals or conferment's. When in a company there is positive cash flow, the company has three choices in front of itself about how to use it: 1- distribute it as a dividend or share repurchase among shareholders. 2- Distribute it among loaners.3- keep it in the company as financial assets. (to increase the balance of cash) In return, the negative free cash flow is being created when a company in its operational activities loses cash. Any company which produces negative free cash flow should compensate it on through three sources: 1- Financing through shareholders. 2- Financing through loaners. 3- A fall in the balance of cash flow.

\section{Literature Review}

Relating to investigations on dividend profit effects on predictability power of future cash flows of Iran, some researches have been done in Iran and other countries, among which some of the most important are presented below:

The results of Bahramfar and Mehrani (2004) research showed that there is a direct relation between profit of each share and predicted profit. In other words, by increasing the profit of each share and predicted profit, the dividend profit will increase. The results of Khoshtinat and Hajian (2008) research showed that increasing dividend profit affects the volume of share transactions and reaction of investors to news of increasing dividend profit, is short term. The results of Bararnia Adabi (2004) research showed that investment opportunities, size of company and dividend profit of previous year affects dividend profit policy but financial fulcrum variable does not affect dividend profit. The results of Kordestani (1995) showed that accounting profit has more power of predicting future cash flows compared to cash flows. The results of Modarres and Abbas zadeh (2008) research shows that cash flows have more monetary ability in predicting profits and in contrary we can predict cash flow through profits and predict profits through cash flow. The results of Arab mazaryazdi and Safar zadeh (2008) research showed that profit components, reflects different information about future cash flows. So with separation of profit's committing component to more components, the explaining power of prediction model of cash flows will develop. The results of Bashiri (2008) research show that there is a significant relation between monetary situation and company's profit division. The results of Gourabi (2003)research show that examination of research hypotheses shows insignificance relation between fluctuations in cash cycles, changes in dividend profit of each share and changes in profit of each share. The results of Pour heidari and Khaksari (2008) research showed that the effect of operational cash flow factors on profit division policy of company is higher compared to two factors: dividend profit process in past and net profit growth rate. In the research of Etemadi and Chalaki (2005) operational profit, profit of each share and cash flows are considered as function evaluation criteria. The results of hypotheses examination showed that amount of dividend profit, are a function of profit of each share, operational profit and operational cash flows respectively. 
The results of Kumar (2003) research showed that company and management ownership degree affects positively and significantly and foundational ownership affects reversely on divided profit level. No evidence certifies a significant relation between foreign ownership and profit division policy. The results of Lintner (1965) research using a series of remarks made by companies' managers about effective factors on profit division polity show that dividend profit depends relatively to current income of company and last year's dividend profit. The research of Ling et al (2008) showed that profitable companies with lower risk have higher profit division compared to other companies. The results of Dechow et al (1998) research shows that historical profits have better predictability of future operation processes compared to historical cash flows. The results of Finger (1994) research showed that current cash flows are a better predictor of short term periods compared to current profits. Krishnan and Larki (2000) showed that the researchers carefully compare cash flow predictions for models which use direct and indirect methods for operations. The results of Dichev et all (2009) research showed that among monetary components, the money paid to investors have the most stability. Also they found that paid money to investors had a significant relation with price of share.

\subsection{Research hypothesis}

In the present research we are looking for getting aware of this issue that whether there is a relationship between oncoming cash flow as the dependent variable and other variables such as dividend as the independent variable or not?

\subsubsection{Premise of the research:}

If the distribution of dividend on the prediction of oncoming cash flow has an influence in Tehran Stock Exchange listed companies.

\subsubsection{Premises of the research:}

1) The distribution of firm size has an influence on free cash flow in Tehran Stock Exchange listed firms.

2) The distribution of firm size has an influence on the operational cash flow in Tehran Stock Exchange listed firms.

\subsection{Operational definition of variables:}

In the present research dependent variables and independent variables are being defined as follows:

- Dividend (distribution of cash among shareholders)

$>$ In the article 239 of the trade law in Iran dividend is being defined as: "dividend is a net profit of a company during a fiscal year minus former financial losses and the above-mentioned legal saving in the article238 and other voluntary savings plus dividend from past years which is not being divided". The above-mentioned savings in the article238 involve one twentieth (1/20) of the net profit (i.e.net profit after calculating the sustained losses in previous years) as a legal saving. (Tehran Stock Exchange, 2010).

$>$ Gordon Growth Model (GGM)

1- GGM hypothesizes that the dividend grows by a fixed rate. $D_{t}=D_{0}(1+g)^{t}$

2- GGM is a simplified shape of DDM.

3- GGM is operational only when the expected growth rate $(\mathrm{g})$ is less than the nominal growth rate. (Raiiszadeh, 2009)

Dividend= operational cash flow- cash flow from operational activities for crossing operations

- Firm size: To measure the variable of firm size several criteria such as normal logarithm of the

value of the market, the rights of shareholders, normal logarithm of the total assets of the company,

Logarithm of the whole amount of company sale and the official value of the whole assets of the company can be used.

As it was being mentioned, the influence of company size which was being reported by Lorek and Willinger (2009) led to the manifestation of this issue that whether the distribution of cash among shareholders(dividend) is definitely a determining factor to influence the company size or not. The performed analyses produced a fundamental basis or criterion about the influence of firm size by means of the recent research data and finally it evaluates the potentiality of distributing cash among shareholders until it can approve it after controlling the influence of company size on them. The influence of company size in the present research is being reported by means of four portfolios about company size while 
the annual sales revenue for a (t) period (e.g. the end of measuring period) is a determining factor for company size. Another common and practical determining factor for the company size is sum of assets (total assets) of the company. Anyway, the influence of operational rate (value) and the application of conservative account causes the downplaying or devaluation of the total assets and decreasing the affectivity or effectuality of this measurement as a determining factor for company size. (Lorek \& Willinger, 2009).

In the present research to measure the company size the normal logarithm about the sales revenue and the total assets of the company are being used that is:

Log firm size $=$ Log (Sale Revenue)

Log firm size $=\log ($ Total Asset)

Thus to measure the sales revenue and the total revenue we have the following:

Sum of assets= Revenues- Revenues before extra articles

Sales revenue= free cash flow+ operational cash flow- cash flow for investment

- Oncoming cash flow Our principle and dependent variable in this research is the oncoming cash flow which is being divided into the following parts:

A) Operational cash flow(cash flow for operation)(CFO):Operational cash flow(CFO), is the cash flow which is being created as a result of the operation of the company which is usually being obtained through subtracting the total operational costs from revenues but a series of modifications are being done on the net profit. One of the methods for measuring the operational cash flow is being described as the following:

Operational cash flow= profit before interests and tax+ amortization costs- taxes

The cash flow settlement or list which is being formulated based on the US Generally Accepted Accounting Principles (GAAP) is being started by the profit which is being obtained after receiving the tax and the exceptional articles and then some modifications are being done for the amortization of the fixed assets cost, non-operational profit (or loss) out of selling the fixed assets, changes in the working capital, changes in the interest payable, and the payable value added and the investment revenue. While the cash flow list (financial statements) based on International Financial Reporting Standards is being started by the profit before the tax (receiving) and the unexpected articles and based on the accounting standards in Iran. Operational cash flow can be used to control the craning quality. For instance, if a company in its income statements reports its assets but its operational cash flow is negative it is probable that it has used bold accounting techniques. (Gholamzadeh Laderi, 2009).

Tehran Stock Exchange is also based on an instruction to accept or enlist the valuable papers, take into consideration the operational cash flow as a criterion for (measuring) the quality of the profit and to accept or enlist the companies and also to classify the listed companies in the first and second rate stock markets.(principle and lateral board) According to the article 9 of the sixth decree out of the above-mentioned instruction, the operational profit out of the applicant company to enlist, the stock market should enjoy a high quality in the fiscal period toward the end of enlistment and the total sum of the net cash flow which is being obtained from the valuable papers in Tehran Stock Exchange, passed in 2007.

B) Free cash flow (FCF): Free cash flow or FCF is a criterion for measuring the function and illustrates the cash flow that remains after subtracting the spending's of the company which allows to follow opportunities that increase the value of the shareholders. Without cash flow, developing the new products, achieving commercial revenues, paying cash profits to shareholders, and decreasing the debts or liabilities will not be possible. (Gholamzadeh Laderi, 2009).

In one of the measuring methods free cash flow is being calculated by means of the following equation:

Free cash flow= net profit+ amortization of fixed intangible and tangible asset- changing the working capital- capital costs

In another method free cash flow is being calculated by subtracting the capital costs from operational cash flow. It should be mentioned that Tehran Stock Exchange in order to make it possible to compare the listed firms and to measure the free cash flow and disclose it in the declaration of accepting and enlisting companies uses this calculating method. Operational cash flow comes at the top of cash flow statement and the net value of capital costs which are being done are also being obtained from the section of investment activities in the mentioned list and by subtracting them the free cash flow for the three previous years (and if possible for the next three years) will be calculated. (The instruction to accept the valuable papers in Tehran Stock Exchange, passed in 2007).

\subsubsection{Research Model:}

Measuring the oncoming cash flow in the form of free cash flow and operational cash flows leads to the presentation of following yearly predicting models: 
1- $F C F_{i, t+1}=a_{i}+b_{i} F C F_{i, t}+\varepsilon_{t+1}$

2- $\quad$ CFOi, $t_{+1}=a_{i}+b_{i}$ CFO

In which FCF equals free cash flow and CFO equals operational cash flow. Cash flows of a period are being predicted as a linear functions of the current cash flows.

\section{Methods Research}

\subsection{Statistical universe and statistical sample of the research}

Statistical universe of the present research is Tehran Stock Exchange listed firms. This sample contains companies that enjoy the following conditions:

1) Companies which have had continuous activity since2006 to 2010 (5-year term).

2) non-investment companies.

3) Companies which the end of their fiscal year is the end of Persian calendar (March).

4) Companies which haven't had any gap in their transactions during the above-mentioned period.

5) Companies which their data is accessible.

The statistical universe of the relevant research involves the chosen companies in the stock market and the research span includes the fiscal year since 2006 to 2010.

According to the above-mentioned limitations, one hundred and twenty one companies were being chosen as the statistical universe of the research and since the census method is being used in this research, the whole one hundred and twenty one companies as samples will be scrutinized. The whole sample companies are in the realm of productive industry.

\subsection{Hypotheses testing Method}

In this research the researcher in summary compares the precision of the model for predicting the cash flow through the following factors:

(1-The amount of dividend share and 2-size of the company) which are different from each other in terms of the amount of distributing cash among shareholders and we use out-of-sample method to measure the free and operational cash flow and then compare the predicted amount of distributed cash flow among shareholders by means of multi-variate regression model with the real amount of distributed cash flow among shareholders for the fourth year and finally reach the percentage of the error of prediction that is:

Absolute percentage of prediction error= real value- predicted value/ real value

The lesser the percentage of error, the more exact the prediction of cash will be.

\section{Results}

\subsection{Describing the research variables (descriptive statistical values of the research)}

At first we get into considering the characteristics of the research descriptive statistics in the present research which is being illustrated in Table 1.

Table 1: descriptive statistical values of the research

\begin{tabular}{|c|c|c|c|c|l|l|}
\hline SIZEt & FCF & FCFi, $\mathbf{t + 1}$ & CFOi, $\mathbf{+}+1$ & Dt & \\
\hline 121 & 121 & 121 & 121 & 121 & Valid data & \multirow{2}{*}{$\mathrm{N}$} \\
\hline 0 & 0 & 0 & 0 & 0 & Missed data & \\
\hline 34.5339 & 2612.636 & 3226.499 & 1226.729 & 3561.161 & Mean \\
\hline 0.5294 & 39.36156 & 98.98449 & 145.82 & 41.61921 & Standard Deviation of Mean \\
\hline 34.5 & 2573.5 & 3445.5 & 520.5 & 3677 & Median \\
\hline 38 & 2136 & 2235 & 1121 & 2975 & Mode \\
\hline 5.75078 & 427.576 & 1075.247 & 1584.01 & 452.1003 & Standard Deviation \\
\hline 33.071 & 182821.2 & 1156156 & 2509088 & 204394.7 & Variance \\
\hline 0.069 & 0.253 & 0.441 & 2.378 & -0.224 & Skewed Ness \\
\hline
\end{tabular}




\begin{tabular}{|c|c|c|c|c|l|l|}
\hline 0.223 & 0.223 & 0.223 & 0.223 & 0.233 & \multicolumn{2}{l|}{ SD of Skewedness } \\
\hline 31 & 2214 & 2249.5 & 323 & 3056.5 & 25 \\
\hline 34.5 & 2573.5 & 3445.5 & 520.5 & 3677 & 50 \\
\hline 38 & 3024.25 & 4111.25 & 1602 & 3999 & 75 & \\
\hline
\end{tabular}

D2= (dividend share), FCF= (free cash flow), CFO= (operational cash flow), firm size

According to the obtained amounts it can be said that the logarithm of firm size has the least coefficient of variations; so it has had the maximum amount of constancy and stability during a five-year term and the variable of free cash flow has the maximum coefficient of variations so it has the minimum amount of constancy and stability in a five-year term among the variables of the research. The above-mentioned statistical value is indicative of the intense changes and fluctuations in free cash flow during the five-year term of research.

\subsection{Statistical analysis of the research variables}

Scrutinize the research hypotheses, the correlation coefficient and the regression coefficient and also the constructive equations are being used. At first, to scrutinize the premises of the research, constructive equations method which is an approximate model of simultaneous regression will be used. Like regression, the precondition of using the regression is the normality of the dependent variable of the research. Thus, Kolmogorov-Smirnov test is being used to scrutinize the normality of the research variable.

The results which are being obtained from regression can be valid if its relevant preconditions are in use. The precondition to use the regression test for a series of variables is the continuity of the dependent variable and enjoying a normal distribution. Also, the remainders or leftovers should be independent and have a normal distribution.

To scrutinize the normality of the variable (cash flow=CF), Kolmogorov-Smirnov test was being used.

At first we consider the null hypothesis $(\mathrm{H} 0)$ and the alternative hypothesis $(\mathrm{H} 1)$ as the following:

1) $\mathrm{H} 0=\mathrm{F}(\mathrm{x})=\mathrm{Fe}(\mathrm{x}) \rightarrow$ for all the questions relevant to the range. (Distribution is normal).

2) $\mathrm{H} 1=\mathrm{F}(\mathrm{x}) \neq \mathrm{Fe}(\mathrm{x}) \rightarrow$ At least for a quantity relevant to the range (Distribution isn't normal).

Table 2: Illustrates the descriptive statistics of the mentioned test and Results of Kolmogorov-Smirnov test

\begin{tabular}{|l|l|c|}
\hline Normal Distribution Parameters & Mean & 3561.1610 \\
\hline \multirow{4}{*}{ Maximum differences } & SD & 452.10034 \\
\cline { 2 - 3 } & Absolute Value & 0.105 \\
\cline { 2 - 3 } & Positive & 0.131 \\
\cline { 2 - 3 } & Negative & -0.150 \\
\hline Kolmogorov-Smirnov value & 0.401 \\
\hline Approximate Meaningfulness Level & 0.997 \\
\hline
\end{tabular}

To consider the normality of the remainders a histogram and a graph of the probability of the normality can be used. (Chart 1).

(Dependent variable=FC)

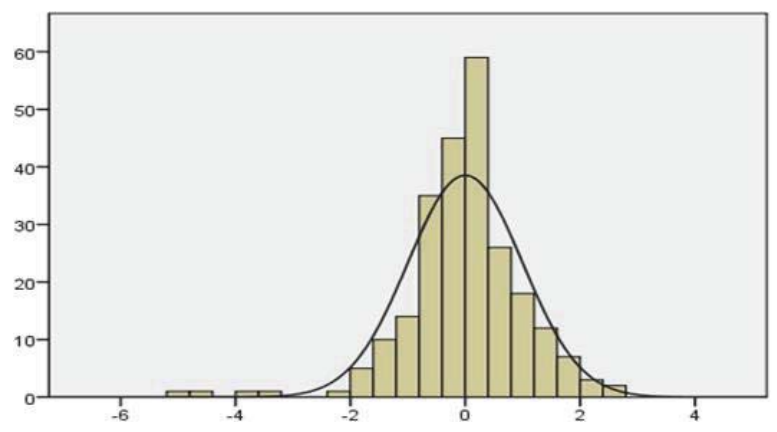


Chart 1: Normal distribution of FC

According to the above diagram, it will be clear that the amounts of remainders have an almost normal distribution with an approximate mean of zero and a standard deviation of one.

\subsection{Test of the research premises}

The research premises are as follows:

1) Distribution of firm size influences the free cash flow in Tehran Stock Exchange listed firms.

2) Distribution of firm size influences the operational cash flow in Tehran Stock Exchange listed firms.

Now we can see the coefficients of the path and the amount of the influence of firm size in the free and operational cash flows in Chart 2.

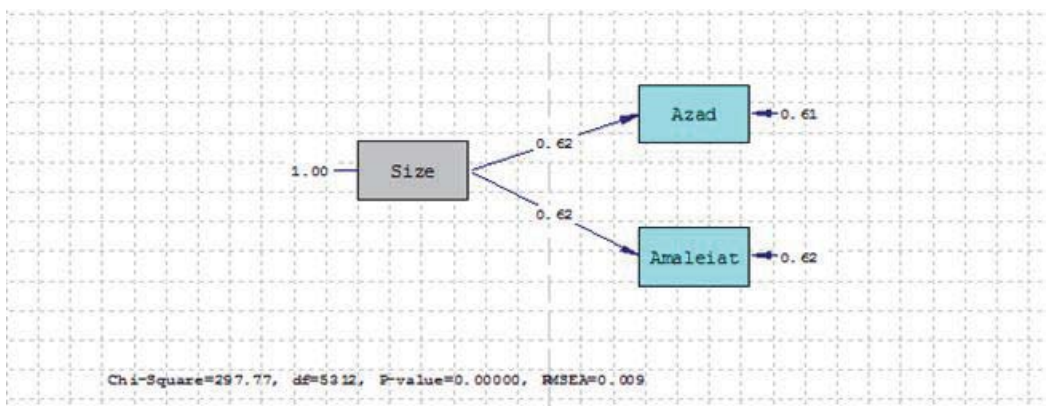

Chart 2: According to the above diagram it will be made clear that per a unit of change in the firm size, it has $62 \%$ or unit of influence on the free and operational cash flow and these two amounts are equal.

\subsection{Test of the research premise}

Distribution of dividend influences the predictions about the oncoming cash flow in Tehran Stock Exchange listed firms. To scrutinize the above-mentioned hypothesis the regression coefficient will be used. Table 3 illustrates the output of this test:

Table 3: Estimated regression values of the premise

\begin{tabular}{|c|c|c|c|c|c|c|}
\hline Error level & $\mathrm{T}$ & Standard coefficient & \multicolumn{2}{|c|}{ Non-standard Coefficient } & \multicolumn{2}{|c|}{ Model } \\
\hline \multirow{2}{*}{0.000} & \multirow{2}{*}{5.214} & Beta & $\mathrm{SD}$ & $\mathrm{B}$ & \multicolumn{2}{|c|}{1} \\
\cline { 3 - 6 } & & & 17.082 & 89.063 & Fixed & \multicolumn{1}{|c|}{1} \\
\hline 0.092 & -1.701 & 0.207 & 0.442 & 1487.075 & $\mathrm{D}_{\mathrm{t}}$ & \\
\hline
\end{tabular}

The results which are being Obtained from table 3 indicates that by a one unit of change in the dividend by an amount of 0.20 (percent), a change in the dependent variable appears. Also, it can be said that $\% 20$ of the changes in the dependent variable (oncoming cash flows) is due to the change in the independent variable (dividend).

To scrutinize the meaningfulness of the multivariate regression we use the variance analysis. In this manner we make the null hypothesis and by means of variance analysis we test it. Table 4

HO: regression is linear.

H1: regression is not linear.

Table 4: Analysis of variance (ANOVA)

\begin{tabular}{|c|c|c|c|c|l|}
\hline Error level & $\mathrm{F}$ & Square mean & $\mathrm{Df}$ & Sum of squares & Model \\
\hline 0.000 & 8.836 & 2890.227 & 5 & 14451.136 & Regression=1 \\
\hline & & 327.102 & 112 & 36635.387 & Remainder Amount \\
\hline & & & 117 & 51086.023 & total \\
\hline
\end{tabular}


As it is being seen in the above table, according to the obtained $\mathrm{F}$ it can be concluded that the independent (predictive) variable is effective in predicting the dependent variable (response) and also by paying attention to the meaningfulness level which equals (0.000), and the issue that this amount is less than 0.01 , so HO hypothesis (i.e. regression is not meaningful) is being rejected by a certainty level of $\% 99$. It means that we can say that regression model is meaningful.

\section{Discussion \& Conclusion}

\subsection{Results of the research}

\subsubsection{Results of the research premise}

The dependent variable of the research (oncoming cash flows) has a normal distribution. So it can be concluded that dividend influences the predictions about the oncoming cash flows in Tehran Stock Exchange listed firms and by paying attention to the correlation coefficient there is a powerful relationship among the variables of the research.

\subsubsection{Results of the research premises:}

In other words the firm size has an equal influence on the free and operational cashflow in Tehran Stock Exchange listed firms.

\subsection{Recommendations based on the research results:}

A- According to the results which are being obtained from the main hypothesis of the future cash flows and the dividend it is being recommended that investors and company managers pay a specific attention to the dividend.

B- According to the results which are being obtained from premises of firm size and free cash flow and operational cash flow, it is being recommended that investors and company managers take into consideration the firm size as well although its influence on the free and operational cash flow is the same.

\subsection{Recommendations for the future researches}

A- Research hypotheses are being tested for non-listed firms and/or for private joint-stock companies and also for state-owned companies and in other words research hypotheses are being tested for listed and non-listed firms.

B- It is being recommended to use bigger firms in the oncoming researches to re-test the influence of firm size on the free and operational cash flows which its influence in the present research was negligible.

\subsection{Research limitations}

The present research like other researches has confronted some limitations which are being listed in the following:

A- Since the company managers do some replacements in the classification of replacements from nonoperational to operational it can cause the prediction of cash flows with problem.

B- According to the economic situations of Iran (inflation and recession situations), it is probable that predicting the oncoming cash flows and oncoming dividend by means of the research model be impossible.

\section{References}

Arab Mazar Yazdi, M., \& Safar Zadeh, M. (2008, Summer). Investigation into the Ability of Financial Ratios in Predicting Financial Distress: Logit Analysis. Quarterly Journal of Securities Exchange(8).

Bahramfar, N., \& Mehrani, K. (2004). Relation profit of each stock, dividend and enterprise in accepted companies in exchange stock of Tehran. The Iranian Accounting and Auditing Review, 11(36), 26-46.

Barar Nia Adabi. (2004).

Bashiri, J. (2008). Affect the liquidity situation of dividend profit in corporation (textile industry), (MA thesis). Tehran, Iran: Technology 
University of Mazandaran.

Dechow, P., Kothari, S., \& Watts, R. (1998). The Relation Between Earnings and Cash Flows. Journal of Accounting \& Economics, 25, 133-168. Retrieved from http://ssrn.com/abstract=928702

Dichev, I., \& Tang, W. (2009). Earnings volatility and earnings predictability. Journal of Accounting and Economics, 47(1-2), 160-181. Retrieved from http://EconPapers.repec.org

Etemadi, H., \& Chalaki, P. (2005, Spring). The relationship between corporate performance and cash dividends in firms listed in Tehran Stock Exchange. The Iranin Accounting and Auditing Review, 12(39), 31-47.

Finger, C. (1994, Autumn). The ability of earnings to predict future earnings and cash flow. Journal of Accounting Research(32), 210223.

Gholamzadeh Laderi, M. (2009). Free cash flow Measure of corporate performance. Financial Accounting Research, 204.

Gourabi, N. (2003). Relationship between changes in cash flow statements items and changes in earnings per share (EPS) and dividend per share (DPS) of the companies listed in Tehran Stock Exchange (Master's thesis). Tehran, Iran: Ministry of Science, Research and Technology, University of Tehran.

Jannat Rostami, M. (1999). Review the role and potential future earnings and cash flows of investing in stocks of companies listed in Tehran Stock Exchange (Master's thesis). Tehran, Iran: Shahid Beheshti University.

Khosh Tinat, M., \& Hajian, N. (2008, Spring). The effect of dividend increase on investor behavior. The Iranian Accounting and Auditing Reviwe, 15(15), 3-18.

Kordestani, G. (1995). Earning Ability for Forcasting Cash Flow and Future Earning. The Iranin Accounting nad Auditing Review, 12(13), $42-55$.

Kumar, J. (2003, September). Does Ownership Structure Influence Firm Value? Evidence from India. The Journal of Entrepreneurial Finance and Business Ventures, 9(2), 61-93. doi:10.2139/ssrn.464521

Larki. (2000).

Ling, F., Abdull Mutali, M., Rizal Shahri, A., \& Said Othman, M. (2008). Dividend Policy: Evidence From Public Listed Companies In Malaysia. International Review of Business Research Papers, 4(4), 208-222.

Lintner, J. (1965, May). Distribution of Incomes of Corporations Among Dividens, Retained Earnings, and Taxes. The American Economic Review, 46(2), 97-113.

Lorek, K., \& Willinger, G. (2009, January). New evidence pertaining to the Prediction Operating Cash Flows. Review of Quantitative Finance and Accounting, 32(1), 1-15. doi:10.1007/s11156-007-0076-1

Modarres, A., \& Abbas Zadeh, M. (2008, Fall). The impact of accruals and cash flow components to predict the quality of the predicted earnings. Knowledge and Development, 15(24), 205-239.

Pour heidari, O., \& Khaksari, M. (2008). Examining the Determinants of Dividend Policy over Tehran Stock Exchange (TSE). Iranin Journal of Development and Capital, 1(2), 183. Retrieved from magiran.com/p662714

Pourheydari, O., \& Ghasemian, A. (2010). The Impact of Firm-Specific Attributes on the Relevance of Cash Flow and Dividend Changes. Journal of Accounting Advances, 2(1), 39-66.

Raiiszadeh. (2009).

Tehran Stock Exchange. (2010). Tehran, Iran. 